\title{
Chapter 2 \\ Politics of disorder: \\ the social unrest in Honiara
}

\author{
Matthew Allen
}

The rioting and looting that broke out in Honiara, the capital of Solomon Islands, immediately after the parliamentary election of the new prime minister in April 2006, and the national election two weeks earlier, highlight the deepseated structural issues that continue to plague this fledgling independent South Pacific nation. The prime minister-elect, Snyder Rini, resigned a week after he was elected in the face of a parliamentary vote of no confidence and was succeeded in the nation's top position by Manasseh Sogavare. Two Members of Parliament were arrested on charges relating to the riots, parliamentary sittings were 'locked down' by the commissioner of police, parliamentarians travelled to and from Parliament House under heavily armed Australian and New Zealand police and military escorts and the Regional Assistance Mission to Solomon Islands (RAMSI) and the Solomon Islands Police Force (SIPF) were criticised by MPs for interfering with the political system.

This chapter examines the 2006 national election and seeks to offer some explanation for the social unrest that saw the looting and destruction of numerous Chinese-owned businesses in Honiara. The election, which was declared fair and free by international observers, exhibited all of the elements that have come to characterise elections in the independent Melanesian countries. It was contested by a large number of candidates, meaning that seats were won with very small 'majorities', and by a large number of parties and independents with weak or incoherent policy platforms. There were allegations of vote buying (or 'bag rice' politics) and the bankrolling of electoral campaigns by local and foreign interests. There were also reports of corruption among electoral officers and problems with 
the electoral roll. Moreover, although a record number of women candidates contested, none were elected.

After the election, we saw the inevitable 'numbers game' in the lead up to the formation of a new government and the parliamentary ballot for the prime ministerial position. Parties and independents coalesced to form rival political camps based in the capital's leading hotels and vied to lure one another's members. As has been the case in previous elections, there were widespread allegations that local business interests, particularly Asian businessmen, were closely involved in this political manoeuvring. And, as in the past, there was a sharp disjuncture between the politics of campaigning at the local level and the character of the government that ultimately assumed power.

This last process is perhaps the greatest cause of frustration for the electorate in Solomon Islands and, indeed, for voters elsewhere in independent Melanesia. In the context of an extremely weak party system, election outcomes are essentially indeterminable from the voter's perspective. This, perhaps more than any other factor, was the primary cause of the ostensibly spontaneous riots that broke out after the announcement of the outcome of the parliamentary ballot for the prime minister, particularly as the same coalition that had held the previous government of Sir Allan Kemakeza was returned to power. The electorate had become exasperated with the Kemakeza administration and the inability or unwillingness of RAMSI to arrest the socalled 'big fish' within that government, including Kemakeza himself.

The riots can also be located in the long-standing tradition of Solomon Islanders' resistance to 'alien' and centralised authority (Keesing 1992; Akin 1999). In two previous episodes of rioting and looting in Honiara, in 1989 and 1996, the rioters were Malaitans seeking compensation from the central government for acts of swearing committed by Bellonese (in the 1989 incident) and Reef Islanders (in 1996). These ultimately successful claims saw the invocation of Malaitan kastom, particularly the 'traditional' practice of compensation, as a form of symbolic resistance to the government. There is some evidence to suggest that former members of the Malaita Eagle Force (MEF), disgruntled about having never received the rehabilitation provided for them under the Townsville Peace Agreement (TPA) and later promised to them by the Kemakeza government, deliberately targeted Chinatown as a way of 'lodging a claim against the government' (Stritecky 2001:230). The 
apparent targeting of RAMSI during the riots could also be understood in the context of resistance to perceived foreign hegemony.

Other elements contributing to the social unrest include latent antiChinese sentiments in the context of deepening socioeconomic inequalities and the growing numbers of unemployed young men in Honiara; growing opposition to, and frustration with, RAMSI; alleged mismanagement of the situation by police, particularly the mission's Participating Police Force (PPF); the particular dynamics of the crowd in Melanesia; and suspected attempts by MPs to incite social disorder for political ends. This last element resonates, somewhat alarmingly, with the situation at the beginning of the so-called 'ethnic tension' in 1998-99, when it was argued by then Prime Minister, Bartholomew Ulufa' alu (deposed in the coup of June 2000) that the parliamentary opposition was stirring up ethnic violence deliberately in order to destabilise his government. In that case, the alleged ethnic manipulation drew on long-standing structural grievances to pit Guales against Malaitans, while in the present case it is the Asian business community that has fallen victim to the racial card.

The events in Honiara in 2006 would therefore appear to be another example of a process of instrumentalisation of disorder, which has been used to describe continuing political and social instability in parts of Africa (Chabal and Daloz 1999) and which has been adopted by some commentators to explain the violence and lawlessness that plagued Solomon Islands between 1998 and 2003 (Dinnen 2002; Fraenkel 2004). Moreover, as has been the case since the early 1990s, and in spite of the best efforts of RAMSI's economic governance and the machinery of government programs, the drama of politics in Honiara continues to unfold against a backdrop of systemic corruption in the key export sectors of forestry and fisheries. It is these lucrative but non-renewable resources that continue to provide the bulk of spoils of the politics of disorder in Solomon Islands.

\section{The 2006 national election and the formation of government}

The national election of 5 April 2006, and the subsequent formation of government, exhibited many of the characteristic elements of elections and national politics in the post-colonial Westminster-style democracies of Melanesia, particularly Papua New Guinea, Solomon Islands and Vanuatu 
(for a summary of these characteristics, see Reilly 2004 and Morgan 2005). A record 453 candidates, including 26 women, contested the 50 parliamentary seats, making an average of about nine candidates for each constituency. As a consequence, seats were won with small majorities: an average of about 31 per cent of the vote, with more than half of all elected MPs polling less than 30 per cent of the vote. As observed by Jon Fraenkel, a factor contributing to the unprecedented number of candidates was the increasing use of dummy candidates, who were engaged by candidates to split rivals' supporters (Solomon Star 2006g). ${ }^{1}$

A record 12 political parties also contested the election, although of the 50 elected MPs only 16 had submitted a party affiliation with their nominations (Solomon Star 2006g). There was a high turnover of MPs, with only 50 per cent of incumbents holding their seats. No women candidates were successful. The turnover rate varied across the country: it was lowest in Western and Choiseul provinces and highest in Honiara and Isabel Province (Solomon Star 2006g). As in previous elections, and as is frequently the case in Melanesia, party policy platforms were weak or non-existent and campaigns were focused mostly on specific local issues. Throughout the election campaign, the local media reported allegations of candidates providing 'gifts' to constituents and the bankrolling of electoral campaigns by local and overseas interests, particularly local Asian businessmen and the Republic of China (Taiwan).

While the election was declared free and fair by international observers, domestic observers, candidates and voters reported a number of problems. Domestic observers in the three Honiara constituencies complained about problems with the voter registration lists, whereby significant numbers of voters who had claimed to be registered correctly were unable to find their names on the lists and were turned away from polling booths (Solomon Star 2006b). It was also reported that some voters were able to remove the so-called indelible ink that was placed on voters' fingers to prevent them from voting more than once. In the Central Kwara'ae constituency (Malaita Province), complaints were made in relation to the poor printing and layout of ballot papers, which made it difficult for illiterate voters to associate candidates' names with their symbols (Solomon Star 2006c). In the Gela constituency (Central Province), it was alleged that some candidates' symbols were not present on the ballot papers (Solomon Star 2006d). 
Perhaps the most serious allegations relate to the rigging of electoral rolls and interference by candidates in the selection and appointment of electoral officials. Complaints were made about the rigging of electoral rolls in the Gela and Central Honiara constituencies (Solomon Star 2006d, 2006f) and in Gela it was also alleged that the winning candidate had hand-picked the electoral officers (Solomon Star 2006d). On a more positive note, the move from a multiple to a single ballot-box voting system was reported widely as having simplified the voting process and very few invalid votes were recorded.

Events after the national election exemplify the fluidity of party politics in Solomon Islands. A week after the election, three camps had formed and were vying to woo one another's members (Solomon Star 2006e). A coalition comprising the National Party, Liberal Party, Solomon Islands Social Credit Party (Socred), Solomon Islands Party for Rural Advancement and a number of independents were camped at the Iron Bottom Sound Hotel. The Association of Independent Members of Parliament (AIMP) was camped at the Honiara Hotel, which was owned by the association's president, Sir Thomas Chan. The third grouping - comprising the People's Alliance Party of caretaker Prime Minister, Sir Allan Kemakeza, and his previous coalition partner, Lafari — were based at the prime minister's residence at Vavaya Ridge. Five days later, on the eve of the parliamentary election for the new prime minister, the People's Alliance Party had joined the AIMP camp at the Honiara Hotel, while Sogavare's Socred Party had left the Iron Bottom Sound Hotel camp to form a new coalition with the One Nation Party and members of the Lafari Party, basing themselves at the Pacific Casino Hotel, reportedly with the backing of local businessman Bobo Dettke (Solomon Star 2006f). There were widespread rumours circulating in Honiara that vested interests, particularly local Asian businessmen, were offering bribes and inducements to MPs in relation to the formation of coalitions in the lead up to the election of the new prime minister.

Three candidates went into the parliamentary vote for the prime minister's post on the morning of Tuesday 18 April, a day now referred to locally as 'Black Tuesday'. Job Dudley Tausinga, MP for North New Georgia and leader of the Solomon Islands Party for Rural Advancement, represented the Iron Bottom Sound Hotel camp; Manasseh Sogavare, MP for East Choiseul, represented the Pacific Casino Hotel camp; and Snyder 
Rini, MP for Marovo and leader of AIMP, represented the Honiara Hotel camp. Sogavare was eliminated in the first round of voting and Rini defeated Tausinga in the second round and was declared the new prime minister.

\section{Black Tuesday: the aftermath of the parliamentary ballot}

The crowd that had gathered outside Parliament House greeted the announcement of the new prime minister, made about midday, with anger. Prime Minister Rini's statement to the crowd was met with insults, jeers and shouts of 'Asian money, Asian money' (ABC 2006). The events that followed remain unclear. According to some eyewitness accounts, the crowd had started to calm down after addresses made by a number of leaders, including Job Dudley Tausinga, Sir Peter Kenilorea and Bartholomew Ulufa'alu. It is claimed that PPF officers then decided to use tear-gas to disperse the crowd against the advice of Solomon Islander police officers (Confidential sources, Honiara). According to other sources, tear-gas was used after stones had been thrown at the police and a police vehicle had been sprayed with petrol and set alight. The use of tear-gas angered the crowd and seems to have immediately contributed to the riots, which resulted in the looting and burning of Chinese-owned retail stores in Chinatown and the Point Cruz and Ranandi areas, and the torching of several police vehicles.

The rioting and looting continued into the next day when the Pacific Casino Hotel (owned by businessman Patrick Leong) was burnt down and more police vehicles were destroyed. It was announced that military and police reinforcements were en route from Australia and New Zealand and that the governor-general had declared a curfew under the Preservation of Public Security Act. A petition was presented to the governor-general demanding the resignation of the prime minister. The petition was passed onto Rini, who promptly rejected it (SIBC 2006b). The situation had started to stabilise by Wednesday after the arrival of 120 soldiers and 30 police from Australia and a further 30 soldiers from New Zealand and 20 from Fiji. There were still, however, small pockets of unrest in the Kukum and Ranandi areas of Honiara (SIBC 2006c). During the two days of violence, 17 PPF officers and an unknown number of Chinese people, including children, sustained injuries. On Thursday, it was reported that 14 people had been arrested in the Malaitan township of Auki on suspicion of attempting to cause unrest 
there on the Tuesday evening (SIBC 2006c). Apart from this incident, the riots had been confined entirely to Honiara.

Rini was officially sworn in as prime minister on Thursday 20 April and, by the weekend, Sir Peter Kenilorea had been renominated, unopposed, for the position of Speaker of Parliament. On the Sunday night, Police Commissioner, Shane Castles, announced that the next day's parliamentary sitting to elect the deputy speaker — which was being contested by Sir Allan Kemakeza as the government's candidate and Patteson Oti for the opposition - was to be closed to the public. Sunday also saw the arrest of the Member for Central Honiara, Nelson Ne'e, on charges related to the riots. Another MP was arrested for breaking the curfew and was released on bail. Police were also seeking a third MP (Member for East Honiara, Charles Dausabea) for charges related to the riots, after they failed to capture him during a raid on his room at the Mendana Hotel on Sunday night (Solomon Star 2006g).

The political drama intensified as parliament resumed sitting on Monday under lock-down and a heavily armed police and military presence. Opposition spokesman and candidate for the deputy speaker's position, Patteson Oti, requested that the vote for the deputy speaker be postponed, arguing that the opposition was disadvantaged by the absence of one of its members, who was in police custody (Nelson Ne'e). Oti also challenged the closure of Parliament House as unconstitutional. There was also discussion in parliament of a vote of no confidence to be moved in the coming days. Immediately after the swearing in of MPs, members of the opposition absented themselves. Dausabea attended the parliamentary sitting but was arrested by plain-clothed detectives as he was leaving the house and charged with offences relating to the riots (SIBC 2006d; Solomon Star 2006h). Ne'e had his bail application rejected at the Magistrates Court.

Parliament resumed sitting the next morning under lock-down. Parliamentarians arrived under heavily armed police and military escorts. Overnight, the minister for police and national security, the police commissioner and the prime minister had all made statements rejecting claims by the parliamentary opposition that the arrest and continuing detention of two of its members were politically motivated (SIBC 2006h; Radio New Zealand 2006b). Oti once again objected to the lock-down of parliament, but the speaker upheld the situation, citing the separation of 
powers under the constitution. The speaker also insisted that parliament proceed with the election of the deputy speaker. Ulufa'alu then led an opposition walk-out from parliament, appealing to any MP 'with an ounce of Solomon Islands blood in him' to walk out with him (SIBC 2006e). Kemakeza was elected deputy speaker in the absence of the opposition. Dausabea had his bail application refused at the Magistrates Court under tight security.

The political situation reached a climax on Wednesday. Five members of the government (including four ministers), led by Sogavare, crossed the floor, giving the opposition a 28-20 majority. Before tabling the vote of no confidence, Oti demanded that the prime minister 'do the honourable thing' and resign. Parliament was adjourned for 15 minutes and, when it resumed about $10.15 \mathrm{am}$, Rini announced his resignation. There was immediate jubilation on the streets of Honiara as taxis, buses and private vehicles sounded their horns and a large crowd made its way down to the Iron Bottom Sound Hotel to congratulate the opposition on its victory. There was a general feeling of relief in Honiara that eight days of intense political and social instability had come to an end, at least for the time being.

\section{What went wrong in Honiara?}

Some of the causes of the rioting and looting that broke out after the election of the new prime minister remain obscure. The sequence of events that occurred at Parliament House on the afternoon of Black Tuesday is contested, as are some of the basic facts relating to those events. The extent to which the outbreak of violence was premeditated also remains unclear. It is possible, however, to identify some factors that arguably contributed to the social unrest. These are now considered.

Frustration with the election outcome and the electorate's inability to influence electoral outcomes

The 2006 national election, and the subsequent formation of government and the second election for the new prime minister, clearly caused a great deal of frustration among the electorate. As in previous elections in Solomon Islands, and elsewhere in Melanesia, the final outcome was entirely unpredictable from the voter's perspective. In the context of an extremely 
weak party and policy environment, campaigns were fought on a parochial basis and had little or no bearing on the final composition of the government. There was no way for voters to know whether elected candidates would stay with their parties, who would form the government and who would be prime minister. Moreover, the electorate was particularly cynical about the circus-like dynamics of political camp formation and reformation. The alleged sponsoring of this process by prominent local businessmen of Asian origin fuelled a widespread belief that those vested interests had a strong influence on the final outcome of the election.

These underlying frustrations were exacerbated by the outcome of the parliamentary ballot for prime minister, which essentially returned to power the same coalition that had constituted the former Kemakeza government, with Kemakeza's deputy, Snyder Rini, the new prime minister. The Kemakeza government was extremely unpopular with the public from the moment it came to power after the 2001 election. Indeed, Kemakeza had been thrown out of the previous (caretaker) government of Sogavare (2000-01) for misleading cabinet and allegedly misappropriating funds in relation to the disbursement of a US\$25 million loan from a Taiwanese bank, for which he assumed overall responsibility at the time as minister for national unity, reconciliation and peace (Dinnen 2002; Moore 2004).

Moreover, although the 2001 election had been declared free and fair by international observers, there is ample evidence to suggest otherwise. The country was still militarised with the ‘joint operation’ fighting Harold Keke on the Weather Coast. Honiara was controlled by ex-MEF militants and other parts of the country, such as North Malaita andWestern Province, continued to experience violence and lawlessness. It was also reported that voters were intimidated at gunpoint in a number of constituencies in Malaita Province and in Rennell/Bellona. The public response to the announcement of Kemakeza's victory in the 2001 election was negative. 'There was a less than enthusiastic reaction from the crowd that had gathered outside the Parliament to hear the results. Nobody cheered when the governor-general made the announcement' (Radio Australia cited in Moore 2004:173).

Since the arrival of RAMSI in Solomon Islands in July 2003, there have been regular appeals in the letters to the editor and editorial sections of the local newspapers to arrest the big fish, including Kemakeza himself. These appeals intensified after the publication in late 2004 of an auditor-general's 
report into the disbursement of the loan mentioned above (Auditor-General 2004) and the subsequent arrest of Lucien Ki'i (Kemakeza's permanent secretary at the time) on corruption charges relating to the disbursement. The return to power of the same ruling coalition — headed by Kemakeza's heir apparent — was, for many people in Solomon Islands, the final fatal act in a process of mass political disempowerment.

Lodging a claim against the government

Anthropologists David Akin (1999) and Roger Keesing (1992) have demonstrated that, since the early colonial period, Malaitan kastom ideologies have had a strong anti-government emphasis. Akin (1999:38) describes how compensation has 'long been a key symbol within Malaitan identity and resistance ideologies'. He locates the riots of 1989 and 1996 within this longstanding tradition of Malaitan, and particularly Kwaio, compensation claims against the government. Akin (1999:58) argues that while many factors were involved in the riots, including increasing urban unemployment and a growing 'rascal' subculture, all were underscored by 'enduring Malaitan discontent with government behaviour'. Drawing on Akin's work, Jolene Stritecky argued that the upshot of the 1989 and 1996 demonstrations in Honiara 'was that committing violence against persons not associated with the government, especially Chinese store owners, became par for the course in the Malaitan strategy for lodging a claim against the government' (2001:230).

Some former MEF militants whom I spoke to on Malaita about six weeks after the 2006 riots claimed that the riots were caused by Kemakeza's failure to pay 'rehabilitation to all the boys', as he had promised to (Confidential interviews). This sentiment is related to a broader and widely held belief among former MEF militants that the Sogavare and Kemakeza governments should have compensated them adequately for their role in securing Honiara, protecting the government and 'saving' the nation during the ethnic tension (Confidential interviews). They are also angry about never having received the rehabilitation provided for them under the provisions of the TPA of October 2000 and later promised to them by the Kemakeza government. ${ }^{2}$ Seen in the historical context of Malaitan claims against the government, the involvement of disgruntled ex-MEF in the 2006 riots is highly plausible, particularly as the election effectively restored Kemakeza's coalition to power. 


\section{Latent anti-Chinese sentiments}

Honiara has a large underclass of disaffected unemployed young men, many of whom originate from the densely populated and historically underdeveloped island of Malaita. These men, known colloquially as masta liu, harbour latent resentment of the local Chinese business community, which to some extent is shared by the populace at large. During campaigning for the national election, candidates for seats in the East Honiara constituency, including Charles Dausabea, expressed concerns about the growth of the Chinese business community at a public forum held in Honiara, claiming that Chinese people were dominating local business and commerce and thereby disadvantaging indigenous Solomon Islanders (Solomon Star 2006a). A few months before the election, a Solomon Islander recounted to me a conversation he had recently had with an indigenous Fijian friend who was visiting from Fiji. His friend warned him that ethnic conflict could arise between Chinese migrants and indigenous people in Solomon Islands as it had in Fiji between indigenous Fijians and Indo-Fijians. His response to his friend's warning was that 'we already have an ethnic conflict with the wakus [Solomons Pijin for Chinese people]'.

Discussions with Solomon Islanders reveal that people distinguish between the long-standing Chinese families (many of whom have been in the country for several generations) and the newly arrived migrants, most of whom have come from Guangdong Province in southern China (see Moore this volume). The latter group, referred to frequently as the 'overnight passports', came into the country in increasing numbers during the social unrest of 1998-2003, allegedly under illegal or improper immigration arrangements. Indigenous Solomon Islanders regard them as being poorly integrated with local society, and they are often stereotyped as being money-hungry, rude and arrogant. It would appear that it was the newly arrived Chinese migrants who were particularly targeted during the riots and looting. Indeed, it is rumoured that the rioters were following a predetermined list of businesses that were to be targeted. The fact that some businesses owned by long-standing Chinese families such as the QQQ store in the middle of Chinatown were spared, indicates that some sort of selective targeting could indeed have taken place. 
Growing opposition to, and frustration with, RAMSI ${ }^{3}$

Since its inception in July 2003, RAMSI has been subject to increasing levels of criticism from certain sectors of Solomon Islands state and society, in particular the public service, parliamentarians and former associates of militant groups, especially the MEF. In late 2005, former MEF spokesman and prominent local lawyer Andrew Nori launched a High Court challenge to the legality of RAMSI, arguing that the legal instrument under which RAMSI operates - the Facilitation of International Assistance Act 2003 (the 'Facilitation Act') — was unconstitutional. The chief justice struck the case down in a lengthy judgement (High Court of Solomon Islands 2006).

Before his arrest, Dausabea, who also had close connections with the MEF, criticised aspects of RAMSI during an interview with Radio New Zealand (2006a). He stated that, as a newly elected MP, he was planning to scrutinise aspects of the Facilitation Act, particularly the immunity clauses, which granted RAMSI officers immunity from prosecution under the laws of Solomon Islands. It had been reported earlier in the local media that Dausabea wanted to 'get rid of RAMSI' (SIBC 2006a) and it was rumoured that he campaigned on an anti-RAMSI platform in the lead up to the 5 April national election.

An anthropologist who spent three months on North Malaita conducting research on the 'lost tribes of Israel' religious cult reports of pervasive antiRAMSI sentiments among the local populace (see Jaap Timmer this volume). The deployment of RAMSI to North Malaita in 2003 was interpreted locally as an invasion of the island by foreign military forces. Moreover, in the teachings of the 'lost tribes' movement - currently enjoying considerable support in parts of North Malaita - RAMSI is described as the anti-Christ.

There is also evidence of growing disaffection with RAMSI among the public service, particularly within the Ministry of Finance, which is the focus of RAMSI's economic governance program. Before the national election, Ulufa'alu said that while there was still unanimous support for RAMSI among MPs, there was growing dissent in the public service (Ulufa'alu, personal communication, 26 February 2006). Concerns revolve around the fact that RAMSI advisers are perceived by local bureaucrats as contractors who are essentially working for private-sector interests, rather than for the public service. Furthermore, it would appear that the public-sector industrial dispute was fuelled by growing agitation among local Ministry of Finance employees concerning the great disparity between local and expatriate 
terms and conditions of employment. In his victory speech, Rini — who had been openly critical of the outgoing Minister for Finance, Peter Boyers, in meetings of the previous cabinet - criticised RAMSI for not doing enough to build the capacity of local staff within the Ministry of Finance (ABC 2006). Concerns about capacity building and counterparting in the Ministry of Finance were also highlighted in a Pacific Islands Forum Secretariat social impact assessment conducted in October 2003: '[a] repeating concern has been raised about the effectiveness of current counter-parting arrangements between RAMSI personnel and local DOF [Department of Finance] staff. Local staff members feel excluded and RAMSI personnel are not coaching/ mentoring or transferring skills to national counterparts' (Pacific Islands Forum 2004:19).

Another factor that arguably contributed to the riots is the gradual erosion, over time, of RAMSI's authority. The 'shock and awe' generated by the initial deployment of RAMSI has well and truly worn off. People are keenly aware of challenges to RAMSI's infallibility, notably the fatal shooting of Adam Dunning in late 2004, which demonstrated that RAMSI did not, after all, have machines that would find all of the guns that hadn't been surrendered. According to an ex-militant and former follower of Harold Keke whom I spoke to on the Weather Coast of Guadalcanal, 'people are no longer afraid of RAMSI' (Confidential interview).

As mentioned above, the general public has voiced considerable frustration with RAMSI's inability or unwillingness to arrest the big fish in relation to crimes committed during the tension. While a number of highprofile parliamentarians have been arrested and charged with tension-related offences - notably Benjamin Una and Alex Bartlett - there are widespread feelings that RAMSI has not gone far enough. RAMSI has also been criticised locally for privileging a Western-style law and order approach at the expense of a Melanesian-style peace and reconciliation process (see Moore 2004:215-19). Calls for RAMSI to give greater support to Melanesian forms of peace building have come from elements of society as diverse as ex-combatants, chiefs, church leaders, public servants and judges, including the chief justice. The review of RAMSI conducted by the Pacific Islands Forum Eminent Persons' Group in June 2005 recommended that a policy paper be prepared to identify suitable models for a truth and reconciliation commission (Pacific Islands Forum 2005:paras 14, 63, 90[xii]). 
The arrest of the two MPs and the lock-down of parliament attracted sustained criticism from MPs; while the allegations that the PPF failed to prevent (and even contributed to) the riots have been the subject of much public debate. There can be no doubt that the riots were disastrous for RAMSI's public image, with members of the public remarking cynically that the military and police reinforcements were too late, just as the original deployment of RAMSI came long after the open armed conflict in Solomon Islands was over. A further publicity nightmare for RAMSI was the leaking of a confidential email written by an Australian official working in the Solomon Islands Ministry of Finance and subsequently sent back to Canberra (Sydney Morning Herald 2006). The email claimed that on the eve of the parliamentary vote for the new prime minister, Australian High Commissioner, Patrick Cole, spoke with Sir Thomas Chan expressing his concern about the suitability of Rini as a candidate for prime minister. The email went on to criticise both candidates for the prime ministership, describing the next day's parliamentary poll as 'a depressing choice... either way things do not look good for the future of RAMSI or the future good governance of SI'.

Just as the riots of April 2006 could be seen partly in terms of the Malaitan tradition of 'lodging a claim' against the government, they can also be seen in the context of long-standing Malaitan resistance to alien authority. Viewed in this light, RAMSI is the latest 'alien' to attract the symbolic opposition of Malaitan kastom. In my discussions with Malaitan ex-militants, kastom was evoked frequently as a challenge to the mission, particularly its policing activities. They point to incidents such as trespassing on tribal lands, breaking into houses without permission and general cultural insensitivity in the way in which RAMSI police, and Australian police in particular, have conducted their operations on Malaita. Indeed, many people on Malaita regard the use of large numbers of armed soldiers and police in a number of failed attempts to capture fugitive Edmond Sae as excessive and tantamount to an invasion of Malaita.

The Malaita Ma' asina Forum also highlights these and other incidents in its denunciation of RAMSI. ${ }^{4}$ The forum executive argues that Malaitans perceive the intervention as an exercise in recolonisation and Australian occupation in the context of broader 'Australian hegemony in the Pacific' (Malaita Ma'asina Forum Executive 2005:21-9). It is further argued that as well as perceptions, 
there have been some real issues (the types of incidents referred to above) that have given rise to growing Malaitan opposition to RAMSI. These issues are ultimately grouped under the rubric of culture: 'There are many cultural issues that for simplicity purposes could be labelled as insensitive to the culture of the people because of dissatisfaction with the Australian-led intervention' (Malaita Ma'asina Forum Executive 2005:21-9).

It is not my intention to engage here in a detailed discussion of local discourses surrounding RAMSI. ${ }^{5}$ It is informative, however, to reflect on statements made by the Malaita Ma'asina Forum Executive (2005:27), which now appear somewhat prophetic. The forum executive warned that the 'long-term physical presence' of RAMSI in the Solomon Islands would 'create an environment for resentment and subsequent resistance' (my emphasis). It stated further that it was predominantly foreigners who were in favour of a long-term occupation and that ' $[t]$ his too will create resistance in due course and it is advisable that good intentions should not lead to violence' (my emphasis) (Malaita Ma'asina Forum Executive 2005:27).

Mismanagement of the situation by the police, particularly the PPF

The extent to which PPF officers contributed to the riots by firing tear-gas at the crowd outside Parliament House on Black Tuesday is the subject of controversy. Former New Zealand parliamentarian and frequent visitor to Solomon Islands Richard Prebble claimed that AFP officers had erred by firing tear-gas at a peaceful demonstration, stating that the '[c]rowd was outraged and the riot spontaneous' (Solomon Star 2006j). The New Zealand Defence Minister, Phil Goff, rejected Prebble's comments during a press conference in Honiara. Goff stated that tear-gas was fired only after a police vehicle had been sprayed with petrol and set alight and stones had been thrown at police, some of whom sustained injuries (SIBC 2006f).

The public debate about the role of the PPF has raised broader issues concerning the cultural appropriateness of the RAMSI approach. For example, a Solomon Islander writing in the 'Private View' section of the Solomon Star stated

I believe the situation could have been cool down [sic] if only RAMSI officers stopped using teargas and let Sir Peter Kenilorea [the speaker] address his own people [Solomon Islanders] on what he has according to the mediation process and restorative justice, which are deemed 
appropriate to [the] Melanesian situation... Therefore let me advise the RAMSI officers and military units, if... any disagreement arises between the leaders and indigenous people of this country [Solomon Islands] please allow Melanesians themselves to take the first approach to try and solve their own internal matters and affairs (Solomon Star 2006j).

The dynamics of the crowd in Melanesia: criminals or voyeurs?

The rioting and looting in Honiara demonstrated aspects of the particular dynamics of crowd situations in Melanesia. In Papua New Guinea, for example, organised events involving large numbers of people, such as cultural shows and rugby league games, frequently end in violence and the use of tear-gas. It would appear that Melanesian crowds can become agitated quickly and without warning. Another element of this crowd dynamic is that after the outbreak of any sort of disturbance, even something as apparently mundane as a lone drunk passing out on the footpath, people will stop whatever they are doing to observe the event. It would appear that many of the so-called rioters and looters in Honiara were law-abiding citizens who had essentially voyeuristic rather than criminal motives. According to people who witnessed the events, these voyeurs - including many women and children - took the opportunity, as everyone else did, of helping themselves to some of the goods that were being looted from the Chinese-owned retail stores.

The role of MPs in inciting the riot: the politics of disorder

Two MPs were arrested in relation to the riots: Charles Dausabea, Member for Eastern Honiara, and Nelson Ne'e, Member for Central Honiara. Both men were members of the Iron Bottom Sound Hotel camp in the lead up to the parliamentary ballot for the new prime minister and, after the ballot, became members of the parliamentary opposition. Dausabea faced charges of inciting violence, threatening violence and intimidation, while Ne'e was charged with two counts of intimidation and one count of managing an unlawful society. Both suspects had their bail applications rejected in the Magistrates Court and the High Court. During Ne'e's High Court bail application, the government prosecutor alleged that he had urged rioters to blow up Parliament House on Black Tuesday, calling out 'dynamitim parliament' (Solomon Star 2006j). Similarly, prosecutors alleged 
that Dausabea had said to the crowd outside Parliament House, ' $[\mathrm{m}]$ i fala lose nao, iu fala doim what nao iu fala likim [we have lost, you do what you want]' (Solomon Star 2006i). It is alleged fur ther that Dausabea had driven through the streets of Chinatown on the evening of Black Tuesday urging rioters to continue looting. According to a witness statement, he told the crowd to 'Go ahead, go ahead, go ahead' (Solomon Star 2006j).

Rumours circulated in Honiara that on Easter Sunday, just days before the parliamentary vote for prime minister, Dausabea organised and sponsored a party at Ten Dollar Beach on the outskirts of town. It is alleged that he plied his guests, predominantly young men, with alcohol and told them that 'if things don't go our way on Tuesday, this is what you're going to do'. It certainly appears that the riots were a mix of premeditation, spontaneity, criminal opportunism and, as noted above, voyeurism. The fact that petrol spray devices were used to torch police vehicles at Parliament House points to premeditation, as do the reports that rioters had a predetermined list of businesses that were to be targeted.

It is not the first time that Solomon Islands MPs have been accused of stirring up social unrest for explicitly political purposes. ${ }^{6}$ It has been argued by some that the outbreak of ethnic violence on Guadalcanal in late 1998 was precipitated deliberately by members of the parliamentary opposition (led at that time by Solomon Mamaloni) who were seeking to reassert control of the state, which had provided them with the lucrative proceeds of corruption in the logging industry during the late 1980s and 1990s. According to the so-called 'opposition conspiracy thesis', the reformist Solomon Islands Alliance for Change (SIAC) government, which came to power in 1997 and was led by Bartholomew Ulufa' alu, presented an unacceptable challenge to a powerful coalition of vested interests, including politicians, public servants and Asian logging companies. Unable to obtain numbers for a parliamentary vote of no confidence, these vested interests sought to stir up trouble on Guadalcanal in order to destabilise the government. According to Ulufa'alu, the 'militancy option' had been in place since the early 1990s, and would have been used to depose then prime minister Billy Hilly in 1994 had he not been forced to resign as a consequence of a number of defections from his cabinet. ${ }^{7}$ From Ulufa' alu's perspective, militancy has for some time been regarded by some elements within Solomon Islands state and society as a 'reserve option when democratic processes fail'. ${ }^{8}$ 
There would appear to be some merit to this argument, at least as it relates to the coup. Greg Fry (2000:302), reflecting on similarities between the coups in Fiji and Solomon Islands, states: '[i]n both coups we note the importance of the middle class businessmen and politicians whose personal wealth and status are tied up with who controls the state...In the Solomon Islands, as in Fiji, the Ulufa' alu Government was introducing anti-corruption regulations which would upset established business connections.' Indeed, the SIAC government's Policy and Structural Reform Program - a mix of home-grown and donor-inspired initiatives - went much further than tackling corruption (Bennett 2000:360, 379-383). The government reduced the number of government ministries, down-sized the public service by 10 per cent and implemented significant reforms in the long-suffering forestry sector, including the drafting of a new Forestry Act and the establishment of a Forestry Board and a Forestry Trust. These reforms 'would have not only reduced the logging quota to a more sustainable level, but also would have seen much more regulation of the industry' (Bennett 2002:10). The 'oppositional conspiracy' theory holds credibility for some long-term observers of Solomon Islands politics (Herlihy 2003; Tony Jansen, personal communication, September 2004).

Although the military-style conflict ended after the TPA, banditry, corruption, intimidation and extortion continued to plague parts of the country - particularly Honiara, North Malaita and the Weather Coast of Guadalcanal - until the deployment of RAMSI in July 2003. Some exmilitants, particularly from the MEF, became indistinguishable from criminal gangs; and ex-militants and politicians benefitted from the abuse of the compensation and demobilisation processes and had vested interests in the prolongation of the lawlessness and disorder. Selected local business houses were awarded duty remissions and tax exemptions during this period (Dinnen 2002), and it was alleged that the backroom dealings also extended to the issuance of new logging concessions to Asian companies. ${ }^{9}$

Commentators have drawn on the work of Chabal and Daloz (1999) in Africa to describe the post-TPA situation in terms of the instrumentalisation of disorder: political élites were perpetuating lawlessness and disorder for their own economic and political benefit (Dinnen 2002; Fraenkel 2004). According to Dinnen (2002:289): '[t]he Sogavare government contributed significantly to the instrumentalisation of disorder over the past two years 
by using compensation as a key instrument in peacemaking.' The apparent involvement of two MPs in the riots could be understood best in the context of this process. There was a brief hiatus in the explicit incitement of violence by political élites after the deployment of RAMSI, it seems, followed by a return to business as usual.

Moreover, while attention has focused on the alleged involvement of local Asian businessmen and Taiwanese money in the recent national election and subsequent second election, the systemic corruption that has characterised the logging and fishing industries continues unabated and, if anything, has worsened since the arrival of RAMSI. Two auditor-general's reports were published in October 2005 cataloguing deepening corruption in the Department of Forestry, Environment and Conservation and the Department of Marine Resources (Auditor-General 2005a, 2005b). While local Asian businessmen and the Taiwanese government could have some influence on politics in Solomon Islands, we must not ignore the lucrative logging deals that have been the key driver of the politics of disorder in Solomon Islands for the past 20 years or so. There is no reason or evidence to suggest that the situation today is any better than it was almost 10 years ago, when Ian Frazer (1997b:67) wrote that popular opposition to the environmental, social and economic inequities of the logging industry 'is pitted against a ruling élite that is far less committed to democratic decision-making and more popular forms of rural development than it is [to] fostering, in its own interest and the interests of foreign capital, intensive exploitation of the last-remaining forests in the country'.

\section{Conclusion}

The 2006 national election and subsequent formation of a government clearly contributed to the riots and looting that broke out in Honiara immediately after the announcement of Rini's victory in the parliamentary ballot for the prime ministership. The election exhibited all of the elements that have come to characterise national elections in post-colonial Melanesia: a large number of candidates and political parties, a high turn-over of MPs, gross under-representation of women, weak or non-existent policy platforms and a strong disjuncture between the politics of campaigning at the local level and the substance of the government that ultimately assumed 
power. There were also accusations of vote buying and the funding of electoral campaigns by local Asian businessmen and the Government of Taiwan. These interests were also widely believed to have been involved in the circus-like formation and reformation of political camps that occurred during the two weeks between the national election and the parliamentary vote for the new prime minister.

This latter process was the greatest single cause of the riots. The electorate felt entirely powerless to exert any influence over the formation of the government and the selection of the new prime minister. The people also felt that it was fundamentally unfair that powerful business interests, including foreign interests, should exert such a disproportionate influence on the political process. The return to power of the enormously unpopular coalition that had held the previous government of Sir Allan Kemakezawith Kemakeza's former deputy as the new prime minister - was, for many people, the final exasperating episode in a political serial over which they had absolutely no control.

There were, however, clearly other factors at play, such as the large numbers of unemployed young men in Honiara who harbour resentment against an expanding Chinese business community, which is perceived as dominating business opportunities at the expense of Solomon Islanders. The recent history of conflict in Solomon Islands indicates that these men provide fertile ground for anyone who is seeking to stir up ethnic hatred and violence (see Fraenkel 2004).

The riots reflect growing frustration in various sectors of Solomon Islands society with RAMSI, particularly its inability or unwillingness to arrest the big fish. There have also been growing expressions of opposition to RAMSI, particularly from Malaitan quarters, and it would appear that the shock and awe that initially provided the intervention force with inviolable authority has eroded over time. The role of the PPF in contributing to the riots remains the subject of controversy and has clearly become politicised. Regardless of which version of the truth is the real one, RAMSI's reputation was damaged in the eyes of Solomon Islanders. Where was RAMSI? Why couldn't it stop the riots?

Former members of the MEF, disgruntled with the failure of successive governments to provide them with the rehabilitation provided under the TPA as well as compensation for their role in saving the nation during the 
ethnic tension, could also have played a key part in orchestrating the riots. This is consistent with the long-standing Malaitan tradition of employing compensation as a means of voicing dissatisfaction with the government. Moreover, it appears that RAMSI has become the latest alien to attract the symbolic opposition of Malaitan kastom.

The particular dynamics of the crowd in Melanesia were an important factor in the riots and looting. A significant proportion of the crowd, it seems, were voyeurs rather than criminals acting with malice aforethought. The spontaneity and speed of the events was characteristic of crowd dynamics in Melanesia.

The last and perhaps most unsettling factor contributing to the riots is the likely involvement of two MPs. The clock has been thrown back to a time before RAMSI, when political élites were able to instrumentalise disorder for their own aggrandisement. It would appear that while the presence of RAMSI could have put a temporary stop to the blatant sponsoring of violence by politicians, the politics of disorder has always been simmering away just under the surface. And while attention has been fixed on the role of local Chinese business and 'chopstick' diplomacy in recent events, let us not neglect the systemic corruption in the fisheries and logging sectors, the proceeds of which have, for many years now, provided the bulk of the spoils of the politics of disorder in Solomon Islands.

\section{Acknowledgments}

I am grateful to Sinclair Dinnen, David Hegarty, Michael Morgan and Ben Reilly for comments on an earlier draft of this chapter, and to Stewart Firth for useful editorial suggestions. I take full responsibility for the content.

\section{Notes}

1 Before the election, Member for Aoke/Langa Langa, Bartholomew Ulufa' alu, described this as a 'new type of politicking' in his constituency, which entailed candidates being paid to stand against him (Bartholomew Ulufa' alu, personal communication, $26 \mathrm{March}$ 2006).

2 The section of the TPA titled 'Rehabilitation of militants' states that former members of the Isatabu Freedom Movement (IFM) and MEF will be repatriated to their home villages at the expense of the national government, and that the government will 'launch 
public works programs' to employ ex-militants, and also provide counselling services for them (Solomon Islands Government 2000:PartTwo, Section 5). Former members of the MEF obviously have high and unrealistic expectations about these rehabilitation provisions.

3 During the riots, torched police vehicles and Chinese-owned businesses were graffitied with the words 'Fuck ramsi'. Other tags included 'Fuck waku', '2006 election corruption', 'Fuck Rini', 'We need a new PM' and 'Born to destroy'.

4 Evoking obvious connotations with the Maasina Rule Movement of the 1950s, the Malaita Ma' asina Forum is a non-governmental organisation that formed in September 2003 'as a voice to raise concerns and issues affecting Malaita and the people of Malaita' (Malaita Ma' asina Forum Executive 2005:3). Although the forum has a management council representing the 33 wards on Malaita, it is unclear how representative it really is. According to informants on Malaita, it has an ambivalent relationship with the provincial government. Kabutaulaka (2006:3) describes it as being 'pushed by a few élites in Honiara to serve their own political agendas'.

5 I have written about local perceptions of RAMSI in Allen (2006).

6 Note that a former minister in the national government, John Maetia Kaliuae, was found guilty of inciting the riots in 1989 (Fraenkel 2004:117).

7 Like the SIAC government, Francis Billy Hilly's National Coalition Partnership (NCP) was attempting to reform the forestry industry, which had become so corrupted under the governments of Solomon Mamaloni (for details of the reforms, see Frazer 1997a, 1997b; Dauvergne 1998-99; Bennett 2000). The NCP barely had a chance to implement the reform program before it was brought down by a series of cabinet resignations and defections in October 1994. It was proven later that five cabinet ministers of the NCP government had defected to join Mamaloni's Solomon Islands National Unity and Reconciliation Party (SINURP) after receiving bribes from Honiara businessman Robert Goh (Kabutaulaka 1997:488). Once in office, the SINURP government immediately set about dismantling the reform program and it was quickly back to business as usual for Mamaloni, who was the director of a logging company, and his ministers, most of whom were also involved in the logging industry (Frazer 1997a, 1997b).

8 Ulufa'alu 2004; taped interview with Bartholomew Ulufa'alu, 25 July 2004.

9 During the period of the conflict, the production and export of all primary export commodities declined; however, proportionately speaking, log exports declined the least and recovered the most rapidly (Central Bank of Solomon Islands 2005). In 2003, the value of log exports exceeded pre-conflict levels, which lends some weight to allegations that several new logging concessions were awarded after the coup in a number of back-door deals (Ulufa'alu 2004; taped interview with Bartholomew Ulufa'alu, 25 July 2004; Tony Jansen, personal communication, 10 September 2004). It has also been alleged that illegal logging activities increased during the period of the conflict (UNDP 2004). 


\section{References}

Akin, D., 1999. 'Compensation and the Melanesian state: why the Kwaio keep claiming', The Contemporary Pacific, 11(1):35-67.

Allen, M.G., 2006. 'Dissenting voices: local perspectives on the Regional Assistance Mission to Solomon Islands', Pacific Economic Bulletin, 21(2):194-201.

Auditor-General, 2004. Report of the Auditor-General into:export import (EXIM) bank loan; other ethnic related disbursements, November, Office of the Auditor-General, Government of Solomon Islands, Honiara.

- 2005a. Special Audit Report into the Financial Affairs of the Department of Fisheries and Marine Resources, October, Office of the Auditor-General, Government of Solomon Islands, Honiara.

- 2005b. Special Audit Report into the Financial Affairs of the Department of Forestry, Environment and Conservation, October, Office of the AuditorGeneral, Government of Solomon Islands, Honiara.

Australian Broadcasting Corporation (ABC), 2006. ABC Radio Australia, 18 April.

Bennett, J., 2000. Pacific Forest: a history of resource control and contest in Solomon Islands, c. 1800-1997, The White Horse Press and Brill Academic Publishers, Cambridge and Leiden.

- 2002. Roots of conflict in the Solomon Islands: though much is taken, much abides: legacies of tradition and colonialism, Discussion Paper 2002/5, State, Society and Governance in Melanesia Program, Research School of Pacific and Asian Studies, The Australian National University, Canberra. Available from http: / / rspas.anu.edu/papers/melanesia/discussion_papers.

Central Bank of Solomon Islands, 2005. Various quarterly and annual reports. Available from http://cbsi.com.sb/index.php.

Chabal, P. and Daloz, J., 1999. Africa Works: disorder as political instrument, James Currey and Indiana University Press, London.

Dauvergne, P., 1998-99. 'Corporate power in the forests of the Solomon Islands', Pacific Affairs, 71(4):524 46.

Dinnen, S., 2002. 'Winners and losers: politics and disorder in the Solomon Islands 2000-2002', The Journal of Pacific History, 37(3):285-98.

Fraenkel, J., 2004. The Manipulation of Custom: from uprising to intervention in the Solomon Islands, Pandanus Books, The Australian National University, Canberra.

Frazer, I., 1997a. 'Resource extraction and the postcolonial state in Solomon Islands', in R.F.Watters andT.G. McGee (eds), Asia-Pacific: new geographies of the Pacific Rim, Hurst and Company, London. 
, 1997b. 'The struggle for control of Solomon Island forests', The Contemporary Pacific, 9(1):39-72.

Fry, G., 2000. 'Political legitimacy and the post-colonial state in the Pacific: reflections on some common threads in the Fiji and Solomon Islands coups', Pacifica Review, 12(3):295-304.

Herlihy, J.M., 2003. 'Marching rule revisited: when the cargo comes', The New Pacific Review (La Nouvelle Revue Du Pacifique), 2(1):185-205.

High Court of Solomon Islands, 2006. Andrew Gabriel Hanaipeo Nori v. Attorney-General, and Sandie Piesley (Commander of the Participating Police Force of the Visiting Contingent to Solomon Islands), and Alan James Morton, Graeme Leigh Marshall, Brett Darren Pattie, PaulWilliam Tubman, Michael David Zschorn and Gavin Alan Campbell, Civil Case No.172-05, 2006, High Court of Solomon Islands (Palmer, C.J.), Honiara.

Kabutaulaka, T.T., 1997. 'Melanesia in review: issues and events, 1996: Solomon Islands', The Contemporary Pacific, 9(2):487-97.

—_ 2006. 'Melanesia in review: issues and events, 2005: Solomon Islands', The Contemporary Pacific, 18(2):423-30.

Keesing, R.M., 1992. Custom and Confrontation: the Kwaio struggle for cultural autonomy, University of Chicago Press, Chicago and London.

Malaita Ma' asina Forum Executive, 2005. Building Peace and Political Stability in Solomon Islands: Malaita Ma'asina Forum perspective, Solomon Islands Publications and Information Distribution Centre, Honiara.

Moore, C., 2004. Happy Isles in Crisis, Asia Pacific Press, The Australian National University, Canberra.

Morgan, M., 2005. Cultures of dominance: institutional and cultural influences on parliamentary politics in Melanesia, Discussion Paper 2005/2, State, Society and Governance in Melanesia Program, Research School of Pacific and Asian Studies, The Australian National University, Canberra.

Pacific Islands Forum (PIF), 2004. Social Impact Assessment of Peace Restoration Initiatives in Solomon Islands, March, Pacific Islands Forum Secretariat, Suva.

— , 2005. Mission Helpem Fren: a review of the Regional Assistance Mission to Solomon Islands, Report of the Pacific Islands Forum Eminent Persons' Group, May. Available from http://www.pmc.gov.sb/files / docs/epg_report_final.doc (accessed 5 May 2006).

Radio New Zealand, 2006a. Radio New Zealand, 25 April 2006. , 2006b. Radio New Zealand, 26 April 2006.

Reilly, B., 2004. 'State functioning and state failure in the South Pacific', Australian Journal of International Affairs, 58(43):479-93. 
Solomon Islands Broadcasting Corporation (SIBC), 2006a. Solomon Islands Broadcasting Corporation, 10 April.

—, 2006b. Solomon Islands Broadcasting Corporation, 19 April.

- 2006c. Solomon Islands Broadcasting Corporation, 20 April.

$\longrightarrow, 2006 \mathrm{~d}$. Solomon Islands Broadcasting Corporation, 24 April.

- 2006e. Solomon Islands Broadcasting Corporation, 25 April.

—, 2006f. Solomon Islands Broadcasting Corporation, 28 April.

Solomon Islands Government, 2000. The Townsville Peace Agreement, 15 October, Townsville.

Solomon Star, 2006a. Solomon Star, 3 April.

—, 2006b. Solomon Star, 6 April.

- 2006c. Solomon Star, 7 April.

- 2006d. Solomon Star, 10 April.

—, 2006e. Solomon Star, 13 April.

—, 2006f. Solomon Star, 18 April.

- 2006g. Solomon Star, 24 April.

- 2006h. Solomon Star, 25 April.

- 2006i. Solomon Star, 26 April.

- 2006j. Solomon Star, 27 April.

Sydney Morning Herald, 2006. 'Solomons a shambles: the email that got away', 1 May. Available at http://www.smh.com.au/news/world/ solomons-a-shambles--the-email-that-got-away/2006/04/30/11463 35611877.html

Stritecky, J.M., 2001. Looking through a moral lens: morality, violence and empathy in Solomon Islands, $\mathrm{PhD}$ thesis, University of Iowa, Iowa City.

Ulufa'alu, B., 2004. Seminar presented at The Australian National University, Canberra, 15 July. Transcript available from http://rspas.anu.edu.au/ papers/melanesia/seminars/04_07_15_sp_ulufaalu.pdf.

United Nations Development Programme (UNDP), 2004. Solomon Islands Peace and Conflict Development Analysis:emerging priorities in preventing future conflict, United Nations Development Programme, New York. 